\title{
Environmental control of nitrate and ammonium uptake by phytoplankton in the Equatorial Atlantic Ocean
}

\author{
Aubert Le Bouteiller \\ ORSTOM, B. P. 1386, Dakar, Senegal
}

\begin{abstract}
At one equatorial fixed position occupied 4 times in 1 yr, 31 in situ uptake experiments were performed with nitrate or ammonium in parallel with carbon fixation incubations. When $\mathrm{NO}_{3}^{-}$ concentration exceeds 0.1 umole in seawater, nitrate uptake is strongly related to the chlorophyll a abundance. Carbon fixation is also related to chlorophyll a. Hence, chlorophyll a would be the best index to predict both new and total production. From 5 to $25 \%$ of the phytoplankton nitrogen needs would be satisfied by nitrate uptake according to the chlorophyll abundance. Specific nitrate uptake rate is correlated to both light and temperature, but there is no significant relation between nitrate uptake and $\mathrm{NO}_{3}^{-}$concentration, which suggests no nitrate limitation when ambient $\mathrm{NO}_{3}^{-}$exceeds about $0.2 \mu$ mole. In the mixed layer without detectable nitrate, results suggest only low nitrate assimilation. For high ${ }^{15} \mathrm{~N}$ enrichment, the maximum nitrate uptake rate was $0.0016 \mathrm{mmole} \mathrm{m}^{-3} \mathrm{~h}^{-1}$ on average in such waters. Total nitrate uptake rate in the photic zone ranges from 1 to $5 \mathrm{mmole} \mathrm{m}^{-2} \mathrm{~d}^{-1}$ Specific ammonium uptake rate is closely coupled to tracer addition. However, it is generally maximum in subsurface and decreases downwards for a fixed ${ }^{15} \mathrm{~N}$ enrichment. Size fractionation experiments suggest that the $<3 \mu \mathrm{m}$ phytoplankton have a preference for ammonium, and the larger ones a preference for nitrate. Previous studies have shown that the $>3 \mu \mathrm{m}$ organisms are only relatively numerous in the chlorophyll maximum whereas picoplankton predominates in the mixed layer but also in nitrate rich waters. Consequently, in this region ammonium would be the principal source of nitrogen for natural assemblages of phytoplankton within the whole euphotic layer.
\end{abstract}

\section{INTRODUCTION}

One of the main objectives of deep-sea ecological research is to quantify the global flux of carbon due to biological processes. The amount of carbon passing from mineral to organic form by photosynthesis represents the gross primary production. Nutrients required by this production come from 2 principal sources: inputs of nutrient-rich deep waters by upwelling and eddy diffusion (= new production) and regeneration of nutrients by heterotrophs within the euphotic layer (= regenerated production) (Dugdale \& Goering 1967, Eppley \& Peterson 1979). In pelagic ecosystems, on large time and space scales, new production is just in balance with output of particulate matter which sinks below the photic layer (Dugdale 1967, Eppley et al. 1983). Hence, new production represents the true fertility index of a given region. The ${ }^{15} \mathrm{~N}$ tracer would be the required tool to measure both new and regenerated production (Dugdale \& Goening 1967). However, one major problem using the ${ }^{15} \mathrm{~N}$ method in the field consists in estimating nitrate or ammonium uptake rate in the open ocean where phytoplankton biomasses are low and inorganic nitrogen concentrations often undetectable (McCarthy 1980, Goldman \& Glibert 1983). The experimental conditions are then crucial and must be considered when interpreting results.

To get estimates of carbon and nitrogen fluxes in the whole euphotic zone, incubations were carried out in situ, which is the simplest way of optimally reproducing natural environmental conditions, particularly temperature and light. From the surface to the bottom of the euphotic layer, temperature decreases by about $10 \mathrm{C}^{\circ}$ in the equatorial Atlantic ocean, which is significant for photosynthesis and growth (Eppley 1972, Li 1980). Furthermore, light spectra are known to change with both depth and the amount of organic matter present in sea-water (Morel 1978, Prieur \& Sathyendranath 1981). Recently, Glover et al. (1985) have demonstrated that blue and green light at depth was 
utilized more efficiently by picoplankton than by many larger algae. The difference between inorganic nitrogen uptake measured under in situ and simulated in situ conditions was found to be rather small in the northwest African upwelling region (Slawyk et al. 1976). The difference however is expected to be higher in the open tropical oceans where picoplankton predominates (Li et al. 1983, Platt et al. 1983, Herbland et al. 1985) and the thermocline is well marked.

If accurate estimates of phytoplankton biomass and production are difficult to obtain in oligotrophic waters, an ecological analysis of the relations between primary production and the main factors affecting this production needs above all that measurements are strictly reproducible. Biomass is undoubtedly the prime factor to consider when interpreting production data. Primary production is of course proportional to biomass if variations of the latter are only quantitative, and not qualitative. One measurement of production for one given biomass would be theoretically sufficient to predict production for any other biomass of the same nature under similar environmental conditions.

In fact, reality is much more complex, particularly because of the numerous possible physiological changes of the plankton, and because of imperfect production and biomass measurements. One given method of production measurement provides only very poor information if applied on only one sea-water sample. On the contrary, the use of several independent methods to measure biomass and production in the same water sample is expected to be much more profitable for a better understanding of the structure and functioning of the marine ecosystem (see for example Laws et al. 1984). In the present study, priority was given to the number of production data collected ${ }^{14} \mathrm{C}$ and ${ }^{15} \mathrm{~N}$ methods). To be comparable, all these data were obtained at the same geographic position, simultaneously with measurements of biomass (chlorophyll

Table 1 Cruises, station numbers, first depth $(\mathrm{m})$ with $\mathrm{NO}_{3}^{-}>0.1 \mu$ mole and depth of the chlorophyll maximum

\begin{tabular}{|c|c|c|c|c|c|c|}
\hline Cruise & Date & Position & $\begin{array}{c}\text { Station } \\
\text { no. }\end{array}$ & $\begin{array}{l}{ }^{15} \mathrm{~N} \\
\text { tracer }\end{array}$ & $\begin{array}{c}\text { Depth } \\
\mathrm{NO}_{3}^{-}>0.1\end{array}$ & $\begin{array}{c}\text { Depth } \\
\text { Chla max }\end{array}$ \\
\hline \multirow{14}{*}{ SOP } & 5 Feb 1979 & $0^{\circ}, 4^{\circ} \mathrm{W}$ & 1 & $\mathrm{NO}_{3}^{-}$ & 35 & 40 \\
\hline & 6 & $0^{\circ}, 4^{\circ} \mathrm{W}$ & 2 & $\mathrm{NH}_{4}^{+}$ & 35 & 45 \\
\hline & 7 & $0^{\circ}, 4^{\circ} \mathrm{W}$ & 3 & $\mathrm{NO}_{3}^{-}$ & 35 & 40 \\
\hline & 8 & $0^{\circ}, 4^{\circ} \mathrm{W}$ & 4 & $\mathrm{NH}_{4}^{+}$ & 30 & 35 \\
\hline & 9 & $0^{\circ}, 4^{\circ} \mathrm{W}$ & 5 & $\mathrm{NO}_{3}^{-}$ & 30 & 40 \\
\hline & 10 & $0^{\circ}, 4^{\circ} \mathrm{W}$ & 6 & $\mathrm{NH}_{4}^{+}$ & 30 & 40 \\
\hline & 11 & $0^{\circ}, 4^{\circ} \mathrm{W}$ & 7 & $\mathrm{NH}_{4}^{+}$ & 30 & 40 \\
\hline & 12 & $0^{\circ}, 4^{\circ} \mathrm{W}$ & 8 & $\mathrm{NO}_{3}^{-}$ & 25 & 35 \\
\hline & 13 & $0^{\circ}, 4^{\circ} \mathrm{W}$ & 9 & $\mathrm{NH}_{4}^{+}$ & 35 & 35 \\
\hline & 14 & $0^{\circ}, 4^{\circ} \mathrm{W}$ & 10 & $\mathrm{NO}_{3}^{-}$ & 45 & 45 \\
\hline & 15 & $0^{\circ}, 4^{\circ} \mathrm{W}$ & 11 & $\mathrm{NH}_{4}^{+}$ & 45 & 50 \\
\hline & 16 & $0^{\circ}, 4^{\circ} \mathrm{W}$ & 12 & $\mathrm{NO}_{3}^{-}$ & 45 & 45 \\
\hline & 17 & $0^{\circ}, 4^{\circ} \mathrm{W}$ & 13 & $\mathrm{NO}_{3}^{-}$ & 35 & 40 \\
\hline & 18 & $0^{\circ}, 4^{\circ} \mathrm{W}$ & 14 & $\mathrm{NH}_{4}^{+}$ & 30 & 30 \\
\hline \multirow[t]{5}{*}{ CIPREA 2} & 22 Apr 1979 & $0^{\circ}, 4^{\circ} \mathrm{W}$ & 134 & $\mathrm{NO}_{3}^{-}$ & 50 & 50 \\
\hline & 23 & $0^{\circ}, 4^{\circ} \mathrm{W}$ & 136 & $\mathrm{NO}_{3}^{-}$ & 50 & 50 \\
\hline & 24 & $0^{\circ}, 4^{\circ} \mathrm{W}$ & 138 & Urea & 40 & 40 \\
\hline & 25 & $2^{\circ} \mathrm{N}, 4^{\circ} \mathrm{W}$ & 140 & $\mathrm{NO}_{3}^{-}$ & 60 & 60 \\
\hline & 26 & $2^{\circ} \mathrm{N}, 4^{\circ} \mathrm{W}$ & 142 & $\mathrm{NH}_{4}^{+}$ & 60 & 60 \\
\hline \multirow[t]{13}{*}{ CIPREA 4} & 20 Oct 1979 & $0^{\circ}, 4^{\circ} \mathrm{W}$ & 1 & $\mathrm{NO}_{3}^{-}$ & 40 & 50 \\
\hline & 21 & $0^{\circ}, 4^{\circ} \mathrm{W}$ & 2 & $\mathrm{NO}_{3}^{-}$ & 40 & 40 \\
\hline & 22 & $0^{\circ}, 4^{\circ} \mathrm{W}$ & 3 & $\mathrm{NO}_{3}^{-}$ & 35 & 45 \\
\hline & 23 & $0^{\circ}, 4^{\circ} \mathrm{W}$ & 4 & $\mathrm{NO}_{3}^{-}$ & 30 & 45 \\
\hline & 24 & $0^{\circ}, 4^{\circ} \mathrm{W}$ & 5 & $\mathrm{NO}_{3}^{-}$ & 0 & 50 \\
\hline & 25 & $0^{\circ}, 4^{\circ} \mathrm{W}$ & 6 & $\mathrm{NO}_{3}^{-}$ & 0 & 40 \\
\hline & 26 & $0^{\circ}, 4^{\circ} \mathrm{W}$ & 7 & $\mathrm{NO}_{3}^{-}$ & 0 & 60 \\
\hline & 27 & $0^{\circ}, 4^{\circ} \mathrm{W}$ & 8 & $\mathrm{NO}_{3}$ & 0 & 50 \\
\hline & 28 & $0^{\circ}, 4^{\circ} \mathrm{W}$ & 9 & $\mathrm{NO}_{3}^{-}$ & 0 & 50 \\
\hline & $\begin{array}{l}20 \\
29\end{array}$ & $0^{\circ}, 4^{\circ} \mathrm{W}$ & 10 & $\mathrm{NO}_{3}^{-}$ & 0 & 50 \\
\hline & 30 & $0^{\circ}, 4^{\circ} \mathrm{W}$ & 11 & $\mathrm{NO}_{3}^{-\frac{1}{3}}$ & 25 & 50 \\
\hline & 31 & $0^{\circ}, 4^{\circ} \mathrm{W}$ & 12 & $\mathrm{NO}_{3}^{-}$ & 40 & 50 \\
\hline & 1 Nov & $0^{\circ}, 4^{\circ} \mathrm{W}$ & 13 & $\mathrm{NO}_{3}^{-}$ & 40 & 55 \\
\hline CIPREA 5 & $18 \operatorname{Jan} 1980$ & $0^{\circ}, 4^{\circ} \mathrm{W}$ & 1 & $\mathrm{NO}_{3}^{-}$ & 35 & 35 \\
\hline
\end{tabular}


a, particulate organic $C, N$ and $P$ ) and environmental factors (temperature, salinity, $\mathrm{O}_{2}$, current, $\mathrm{NO}_{3}^{-}, \mathrm{NO}_{2}^{-}$, $\mathrm{NH}_{4}^{+}, \mathrm{PO}_{4}^{--}$and light). Exactly the same experimental procedures were used at every station. In this way, bias and artefacts are minimized or at least always similar. Then, an ecological interpretation of results may be attempted on data numerous and comparable enough to be statistically significant. The respective natural effects of light, temperature, inorganic nitrogen and chlorophyll a on nitrate and ammonium uptake will be considered from their actual values measured in situ just before or during incubation.

\section{METHODS}

We present here results from $33 \mathrm{~d}$ measurements of in situ nitrogen uptake, of which 31 were made at the same fixed position $\left(0^{\circ}, 4^{\circ} \mathrm{W}\right)$ in the middle of the Gulf of Guinea. This study was performed during 4 different. cruises on the RV 'Capricorne' (Table 1).

Water for measuring nutrients, chlorophyll, particulate matter and primary production was sampled before sunrise with a $30 \mathrm{l}$ Niskin bottle at 8 levels in the euphotic layer, between the surface and $70 \mathrm{~m}$ depth.

Methods used ( $\left({ }^{15} \mathrm{~N}\right.$ excepted) were described in more detail in a previous paper (Le Bouteiller \& Herbland 1984). Nutrients $\left(\mathrm{NO}_{3}^{-}, \mathrm{NO}_{2}^{-}, \mathrm{NH}_{4}^{+}, \mathrm{PO}_{4}^{--}\right.$and at times urea) were immediately analyzed with a Technicon Autoanalyzer (Strickland \& Parsons 1972). Chlorophyll a collected on a Whatman GF/C filter was measured on acetone extracts with a fluorimeter Turner (Yentsch \& Menzel 1963). Particulate matter was sampled before incubation by filtration of 21 samples through Gelman Type A filters. For carbon and nitrogen, a CHN analyzer (Hewlett Packard) was used, and the method of Menzel \& Corwin (1965) was applied for phosphorus assessment. Seawater for production measurement $\left({ }^{14} \mathrm{C}\right.$ method: Steemann Nielsen 1952) was filtered through a $200 \mu \mathrm{m}$ mesh net and incubated in situ in $300 \mathrm{ml}$ Pyrex bottles from sunrise to sunset (mean duration: $11 \mathrm{~h}$ ). Particulate matter was collected on Sartorius filters and radioactivity was counted by the liquid scintillation technique. Water for nitrate, ammonium or urea uptake measurement was also filtered through a $200 \mu \mathrm{m}$ mesh net and poured into $11 \mathrm{l}$ (SOP and CIPREA 2 cruises) or 6 l (CIPREA 4 and 5 cruises) Pyrex bottles. From 0.09 to $1.79 \mathrm{mM} \mathrm{m}^{-3}$ of $\mathrm{K}^{15} \mathrm{NO}_{3}\left(95 \%{ }^{15} \mathrm{~N}\right.$ enrichment; Cadarache-France) was added to each flask so that from 10 to $35 \%{ }^{15} \mathrm{~N}$ $\mathrm{NO}_{3}^{-}$enrichment was obtained in the water for samples collected below the top of the nitracline (Macisaac \& Dugdale 1969), and nearly $100 \%$ enrichment in the nitrate-depleted layer. During in situ incubation in parallel with carbon fixation, from 10 to $15 \%$ of the added nitrate was consumed by phytoplankton in the mixed layer, and less than $5 \%$ in the nitracline. Ammonium additions ranged from 0.01 to 3.57 $\mathrm{mM} \mathrm{m}$ ". Samples were filtered on Whatman GF/C filters and analyzed in a mass spectrometer. Calculations and appropriate corrections were made according to Dugdale \& Goering (1967) and Pavlou et al. (1974). $\mathrm{V}$ (unit $\mathrm{h}^{-1}$ ) is the specific nitrogen uptake rate, and $\rho$ (unit mmole $\mathrm{Nm}^{-3} \mathrm{~h}^{-1}$ ) is the absolute nitrogen uptake rate. $\rho=\mathrm{V}$ multiplied by particulate organic nitrogen. As suggested by Maclsaac \& Dugdale (1969), the particulate nitrogen should be enriched by at least $1 \%{ }^{15} \mathrm{~N}$ for optimal mass spectrometry utilization, So, only samples having a ${ }^{15} \mathrm{~N}$ excess $\geqslant 1 \%$ in the particulate fraction were considered. Hence, some samples from the bottom of the euphotic layer were excluded. In the nitrate-depleted layer, ammonium concentrations below $0.05 \mathrm{mM} \mathrm{m}^{-3}$ were considered as 0 in calculations, because of the poor accuracy of the ammonium analysis for these levels. For deck incubations, samples were collected at about $1000 \mathrm{~h}$ (local time). Subsamples were filtered through a $3 \mu \mathrm{m}$ Nuclepore filter, a $35 \mu \mathrm{m}$ and a $200 \mu \mathrm{m}$ mesh net respectively, and poured into 111 bottles. A $3 \%$ nickel screen covered the incubator cooled with surface sea-water.

Comparison of Gelman Type A with Whatman GF/C filters showed 2 different cases: when chlorophyll a collected on GF/C filters was $<0.2 \mathrm{mg} \mathrm{m}^{-3}$, only 60 to $70 \%$ were retained on Gelman filters, and when GF/C chlorophyll a was $>0.2 \mathrm{mg} \mathrm{m}^{-3}$, then 85 to $100 \%$ were retained on Gelman filters. This will be considered for interpreting results, but data were not corrected.

The downwelling quantum irradiance was measured every day at about $1300 \mathrm{~h}$ (local time) with a Lambda quantameter. Total incident radiation was recorded from a pyranometer (Kipp and Zonen). Light received by samples during incubation (PAR: Photosynthetically Available Radiation) was calculated according to Jitts et al. (1976).

\section{RESULTS}

\section{Nitrate uptake}

Results from 2 stations representative of 2 different typical situations are presented in Fig. 1. Environmental and experimental conditions were quite similar. Both thermoclines and nitraclines are nearly superposable, but at Stn 3 chlorophyll was much richer than at Stn 13. Consequently, the maximum of carbon fixation is well marked in the one case, where chlorophyll is abundant, but not in the other.

Stn 3 represents a 'typical tropical situation' as 

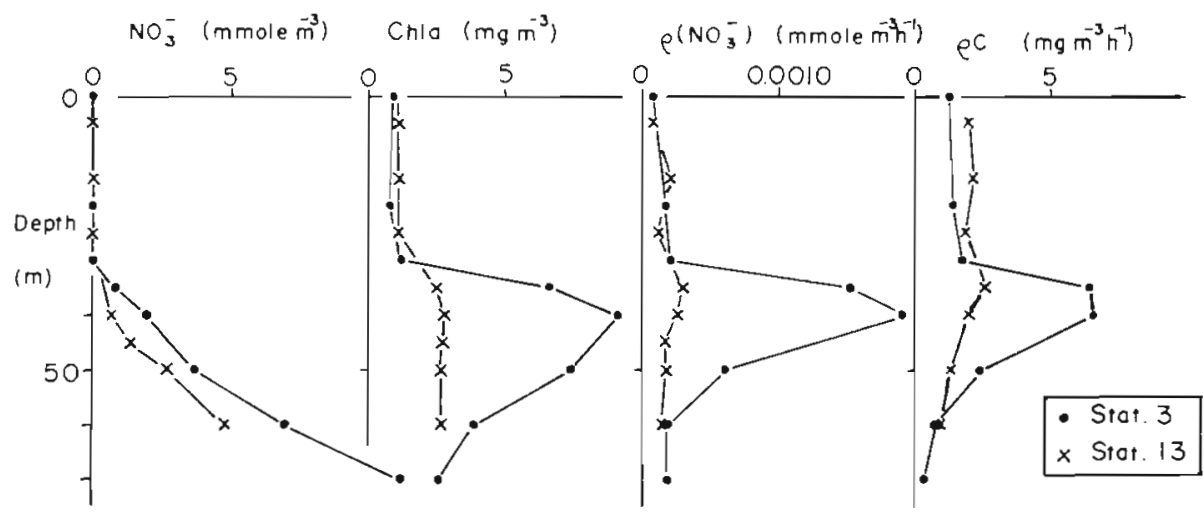

Fig. 1. Depth distribution of nitrate (mmole $\mathrm{m}^{-3}$ ), chlorophyll a $\left(\mathrm{mg} \mathrm{m}^{-3}\right)$, nitrate uptake (mmole $\mathrm{m}^{-3}$ $\left.h^{-1}\right)$ and carbon fixation ( $\mathrm{mg} \mathrm{m}^{-3} \mathrm{~h}^{-1}$ ) at Strns 3 and 13 (SOP cruise). Incident radiation: 1060 and 1040 $\mu \mathrm{E} \mathrm{m}^{-2} \mathrm{~s}^{-1}, \operatorname{Stn} 3$ and 13 respectively, depth of the euphotic layer: 62 and $67 \mathrm{~m}$, duration of in situ incubation: $11 \mathrm{~h} 20 \mathrm{~min}$ and $11 \mathrm{~h} 30$ min respectively described by Herbland \& Voituriez (1979). Peaks of chlorophyll concentration, carbon fixation and nitrate uptake occur at the same depth. This coincidence was obtained many times with depths of the chlorophyll maximum ranging from 35 to $60 \mathrm{~m}$ (= from 8 to $2 \%$ of the light that passed through the surface). Such distributions were also observed in August 1978 at the same position $\left(0^{\circ}, 4^{\circ} \mathrm{W}\right)$ by Slawyk (1980).

Profiles of carbon fixation and nitrate uptake are similar, and this was observed at every station. In a previous paper, we have shown from the same samples that a single equation was sufficient to describe the relation between productivity index $\left(\mathrm{mg} \mathrm{C} \mathrm{mg}^{-1} \mathrm{Chla}\right.$ $\mathrm{h}^{-1}$ ) and available radiation in the euphotic zone, not only for each day of the SOP cruise, but also for CIPREA 2 (at $0^{\circ}$ and $2^{\circ} \mathrm{N}$ ), CIPREA 4 and CIPREA 5 cruises (Le Bouteiller \& Herbland 1984). This means that in the eastern part of the equatorial Atlantic ocean, a single determination of the chlorophyll a concentration provides an excellent description of the potential primary production of that sea-water. For an incident light intensity close to the average, the amount of carbon fixed during daytime can be precisely predicted from the chlorophyll content by means of very simple empirical relations.

Depth of the euphotic layer and incident radiation did not change very much from one station to another,

Table 2. Light conditions for in situ nitrate uptake incubations: depth of the euphotic layer and mean incident radiation reaching surface during incubation. Means of 22 stations, minimal and maximal values. Stn 12 (SOP cruise) conditions are considered apart

\begin{tabular}{|c|c|c|}
\hline & $\begin{array}{l}\text { Depth } 1 \% \\
\text { (m) }\end{array}$ & $\begin{array}{c}\overline{\mathrm{PAR}} \\
\left(\mu \mathrm{E} \mathrm{m}^{-2} \mathrm{~s}^{-1}\right)\end{array}$ \\
\hline Mean & 64 & 1120 \\
\hline Min. & 54 & 790 \\
\hline Max. & 76 & 1420 \\
\hline Stn 12 SOP & 60 & 122 \\
\hline
\end{tabular}

Stn 12 (SOP cruise) excepted (Table 2). Under these conditions, direct comparison of all the production data is of significance. So, all the nitrate uptake rate data from the 24 in situ experiments listed in Table 1 will be considered as representative of a single system. When $\rho\left(\mathrm{NO}_{3}^{-}\right)$is compared to Chla for samples containing nitrate (ambient $\mathrm{NO}_{3}^{-}>0.1 \mu$ mole), a very good relation is obtained (Fig. 2). Eighty \% of the variance of $\rho$ $\left(\mathrm{NO}_{3}^{-}\right)$can be explained by changes of the chlorophyll content. Data for PAR $>\overline{500} \mu \mathrm{E} \mathrm{m} \mathrm{m}^{-2} \mathrm{~s}^{-1}$ were eliminated because of light excess inhibition at surface (see below): depths of samples considered here then range from 15 to $60 \mathrm{~m}$. The regression line equation calculated with data from SOP, CIPREA 2 and CIPREA 5

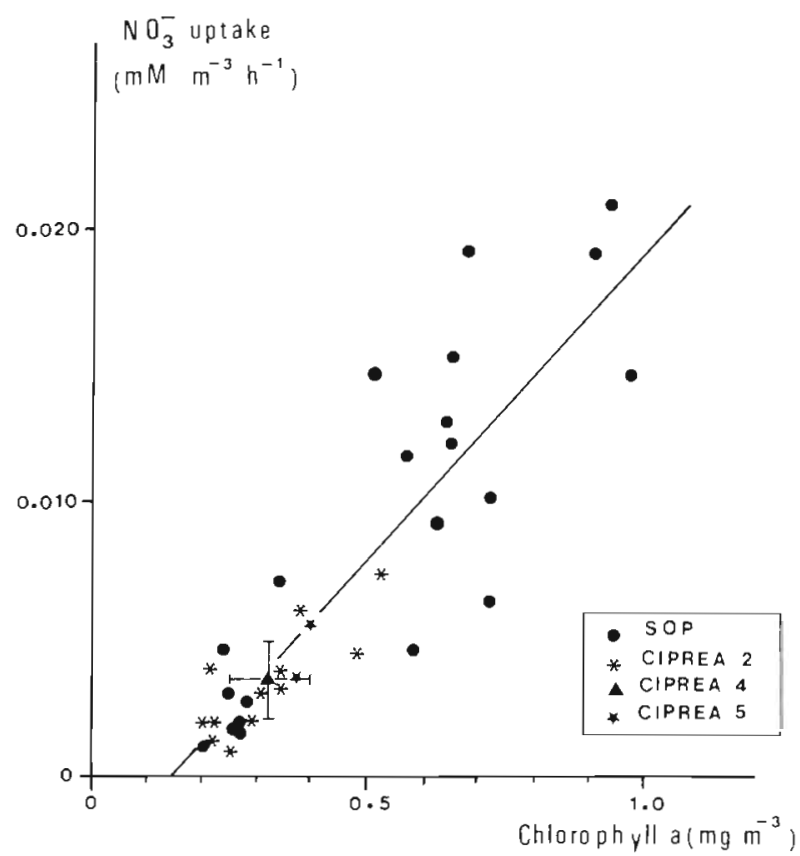

Fig. 2. $p\left(\mathrm{NO}_{3}^{-}\right)\left(\right.$mrnole $\left.\mathrm{m}^{-3} \mathrm{~h}^{-1}\right)$ as a function of chlorophyll a concentration. The regression line computed with SOP, CIPREA 2 and CIPREA 5 cruises data has the following equation: $\rho\left(\mathrm{NO}_{3}^{-}\right)=0.0225 \mathrm{Chl} a-0.0033(33 \mathrm{df}, \mathrm{r}=0.89$, $\mathrm{P}<0.001$ ). CIPREA 4 cruise: mean of 41 data $\pm \mathrm{SD}$ 


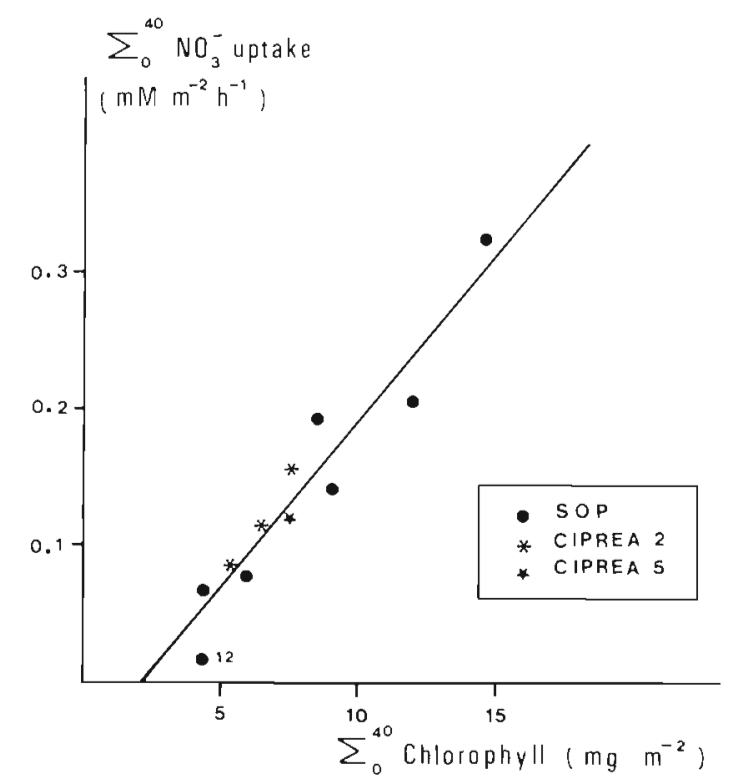

Fig. 3. $\rho\left(\mathrm{NO}_{3}^{-}\right)$vs Chla for the 0 to $40 \mathrm{~m}$ layer. The regression line has the following equation (Stn 12 excepted): $\Sigma_{0}^{40} \rho\left(\mathrm{NO}_{3}^{-}\right)=0.0243 \Sigma_{0}^{40}$ Chla $-0.0527(\mathrm{r}=0.95)$

cruises (Fig. 2) can be used to predict $\rho\left(\mathrm{NO}_{3}^{-}\right)$from Chla data. In this way, nitrate uptake has been calculated from chlorophyll data collected during CIPREA 4 cruise. The calculated and measured mean values of $\rho$ $\left(\mathrm{NO}_{3}^{-}\right)$are respectively 0.0038 and $0.0035 \mathrm{mmole}^{-3}$ $\mathrm{h}^{-1}$, and the difference between the 2 data series is not statistically significant (Wilcoxon test, number of data: 41). Consequently, as for carbon fixation, when light conditions are close to the average, Chla data can be used to predict nitrate uptake with a good precision by means of a simple relation.

A regression line is also obtained between $\rho\left(\mathrm{NO}_{3}^{-}\right)$ and Chla with values integrated by surface unit over $40 \mathrm{~m}$ depth (Fig. 3). The representative point of Stn 12 (SOP cruise) is clearly below the curve, undoubtedly because of the low sunshine that day (Table 2). When integrated over the whole euphotic layer, the absolute nitrate uptake rate varies from 0.09 to $0.40 \mathrm{mmole}^{-2}$ $\mathrm{h}^{-1}$ according to the chlorophyll abundance (depth of
Table 3. Spearman rank correlation coefficients between $\rho\left(\mathrm{NO}_{3}^{-}\right), \quad \mathrm{V}\left(\mathrm{NO}_{3}^{-}\right), \frac{\rho\left(\mathrm{NO}_{3}^{-}\right)}{\mathrm{Chla}}, \mathrm{Chl} a, \overline{\mathrm{PAR}}$, ambient $\mathrm{NO}_{3}^{-}$ and temperature for the same set of samples as in Fig. 2 ( 74 degrees of freedom). $P$ is level of significance

\begin{tabular}{|ccccc|}
\hline & Chla & $\overline{\mathrm{PAR}}$ & $\mathrm{NO}$ & $\mathrm{T}^{\circ} \mathrm{C}$ \\
\hline$\rho\left(\mathrm{NO}_{3}^{-}\right)$ & 0.60 & 0.28 & 0.12 & 0.19 \\
& $\mathrm{P}<0.001$ & $\mathrm{P}<0.02$ & $\mathrm{~ns}$ & $\mathrm{~ns}$ \\
$\mathrm{~V}\left(\mathrm{NO}_{3}^{-}\right)$ & 0.58 & 0.29 & 0.19 & 0.16 \\
& $\mathrm{P}<0.001$ & $\mathrm{P}<0.02$ & $\mathrm{~ns}$ & $\mathrm{~ns}$ \\
& & 0.58 & -0.14 & 0.42 \\
$\frac{\rho\left(\mathrm{NO}_{3}^{-}\right)}{\mathrm{Chla}}$ & - & $\mathrm{P}<0.001$ & $\mathrm{~ns}$ & $\mathrm{P}<0.001$ \\
& & & & \\
\hline
\end{tabular}

the Chla maximum varying between 35 and $60 \mathrm{~m}$ depth).

When nitrate concentration exceeds 0.1 Mmole, $\rho$ $\left(\mathrm{NO}_{3}^{-}\right)$is not directly correlated to the ambient nitrate (Table 3), even if ${ }^{15} \mathrm{NO}_{3}^{-}$addition is considered.

In the mixed layer where $\mathrm{NO}_{3}^{-}<0.05 \mu$ mole, a maximum nitrate uptake rate is obtained with an addition of ${ }^{15} \mathrm{NO}_{3}^{-}$varying from 0.2 to $9 \mathrm{mmole} \mathrm{m}^{-3}$. On the average, $\rho\left(\mathrm{NO}_{3}^{-}\right)=0.0016$ mmole $\mathrm{m}^{-3} \mathrm{~h}^{-1}$ for a mean chlorophyll concentration of $0.11 \mathrm{mg} \mathrm{m}^{-3}$ (Table 4).

$\rho\left(\mathrm{NO}_{3}^{-}\right)$is correlated to the available radiation (Table 3). However, $\rho\left(\mathrm{NO}_{3}^{-}\right)$is an absolute uptake rate whereas a specific uptake rate is more adequate for studying the influence of environmental factors. $\mathrm{V}\left(\mathrm{NO}_{3}^{-}\right)$is a specific nitrate uptake rate directly provided by the ${ }^{15} \mathrm{~N}$ method. Its variations are similar to those of $\rho\left(\mathrm{NO}_{3}^{-}\right)$(Table 3): $\mathrm{V}\left(\mathrm{NO}_{3}^{-}\right)$is strongly correlated to the chlorophyll biomass and also to the light. However, the estimate of $\mathrm{V}\left(\mathrm{NO}_{3}^{-}\right)$is known to be influenced by the amount of non-phytoplanktonic particulate organic nitrogen present in the sample (Dugdale \& Goering 1967). This could explain the relation between $\mathrm{V}\left(\mathrm{NO}_{3}^{-}\right)$and Chla (Table 3 ).

The effect of non-phytoplanktonic PON cancels when $\rho\left(\mathrm{NO}_{3}^{-}\right)$is calculated (Dugdale \& Goering 1967). To get a specific transfer rate, the nitrogen uptake rates

Table 4. Mean values of nitrate uptake, carbon fixation and biomass indexes in the nitrate-depleted mixed layer. $\overline{\text { PAR }}=[100$ to $500] \mu \mathrm{E} \mathrm{m}^{-2} \mathrm{~s}^{-1}$. Chla $=[0.08$ to 0.0136$] \mathrm{mg} \mathrm{m}^{-3}$. POC, PON and POP are particulate organic carbon, nitrogen and phosphorus respectively. Data from SOP, CIPREA 2,4 and 5 cruises. ${ }^{15} \mathrm{NO}_{3}^{-}$added $\geqslant 0.2$ mmole $\mathrm{m}^{-3}$

\begin{tabular}{|c|c|c|c|c|c|c|}
\hline & $\begin{array}{c}\rho \mathrm{NO}_{3}^{-} \\
\text {mmole } \mathrm{m}^{-3} \mathrm{~h}^{-1}\end{array}$ & $\begin{array}{c}\rho \mathrm{C} \\
\mathrm{mg} \mathrm{m} \mathrm{m}^{-3} \mathrm{~h}^{-1}\end{array}$ & $\begin{array}{c}\text { Chla } \\
\mathrm{mg} \mathrm{m}^{-3}\end{array}$ & $\begin{array}{c}\text { POC } \\
\text { mmole } \mathrm{m}^{-3}\end{array}$ & $\begin{array}{c}\text { PON } \\
\text { mmole } \mathrm{m}^{-3}\end{array}$ & $\begin{array}{c}\text { POP } \\
\text { mmole } \mathrm{m}^{-3}\end{array}$ \\
\hline Mean & 0.0016 & 1.71 & 0.108 & 2.77 & 0.33 & 0.021 \\
\hline $\mathrm{SD}$ & 0.0004 & 0.41 & 0.015 & 0.55 & 0.05 & 0.004 \\
\hline No. of data & 23 & 40 & 40 & 40 & 40 & 40 \\
\hline No. of stations & 12 & 20 & 20 & 20 & 20 & 20 \\
\hline
\end{tabular}


were divided by Chla, as was done by Eppley et al (1979), McCarthy et al. (1982) and Kanda et al. (1985). Thus is obtained a nitrate uptake index (mole $\mathrm{N} \mathrm{g}^{-1}$ Chla $\mathrm{h}^{-1}$ ) which is similar to the productivity index $\left(\mathrm{g} \mathrm{C}^{-1} \mathrm{Chla} \mathrm{h}^{-1}\right)$. Calculations show that the nitrate uptake index is significantly correlated to the available radiation (Table 3 ) but not to the nitrate concentration. When the whole euphotic layer is considered (surface excepted), the light effect on nitrate uptake is clearly evidenced (Fig. 4). During experiments, light conditions varied only in a small range from day to day (Table 2). So, no difference of light influence on nitrate uptake by phytoplankton could be detected between cruises. Data from samples without detectable nitrate in the water are included in Fig. 4. However, the relation calculated without data from the mixed layer is not statistically different.

When only experiments with $\mathrm{NO}_{3}^{-}>0.1$ umole at surface are considered (CIPREA 4 cruise, Stn 5 to 10), the nitrate uptake index is always maximum at 15 or 20 m depth, and decreases downwards. The productivity index exhibited a similar vertical distribution (Le Bouteiller \& Herbland 1984)

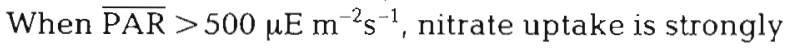
inhibited by light excess: the nitrate uptake index ranges from 0.0080 to 0.0140 mole $\mathrm{N} \mathrm{g}^{-1} \mathrm{Chla} \mathrm{h}^{-1}$ when PAR changes from 750 to $875 \mu \mathrm{E} \mathrm{m}^{-2} \mathrm{~s}^{-1}$ at the surface (5 different in situ experiments).

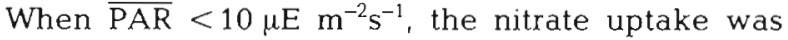
found to be close to zero, which occurred below the euphotic layer (relative radiation $<1 \%$ ) or when the incident radiation was low (for example, Stn 12, SOP cruise: a mean radiation of $10 \mu \mathrm{E} \mathrm{m}^{-2} \mathrm{~s}^{-1}$ was received by the sample incubated at $35 \mathrm{~m}$ depth).
Due to the use of in situ incubations, the temperature effect on nitrate uptake cannot be separated rigorously from the light effect. Schematically, light and temperature both decrease with depth. As a consequence, the nitrate uptake index is highly correlated to both light and temperature (Table 3). When plotted against temperature (Fig. 5) the nitrate uptake index shows variations very similar to those observed with PAR (Fig, 4). However, in the mixed layer, the nitrate uptake index clearly decreases only with light, not with temperature (Table 5). In this case, the amount of available radiation is the controlling factor. As when $\mathrm{NO}_{3}^{-}>0.1 \mu$ mole at surface, the nitrate uptake index is also maximum just above surface in nitrate-depleted waters. From the top to the bottom of the euphotic layer, the nitrate uptake index surely varies in a rather wide range with $P A R$, but the respective influences of light and temperature are still unknown in this area.

\section{Ammonium uptake}

Results from experiments with ammonium as a tracer provide evidence of the prime effect of ${ }^{15} \mathrm{NH}_{4}^{+}$enrichment on $\mathrm{NH}_{4}^{+}$uptake rates.

In the mixed layer, the specific ammonium uptake rate $\mathrm{V}\left(\mathrm{NH}_{4}^{+}\right)$is closely coupled to the amount of tracer introduced (Fig. 6). When ${ }^{15} \mathrm{NH}_{4}^{+}$addition changes from 0.02 to 3.6 mmole $\mathrm{m}^{-3}, \mathrm{~V}\left(\mathrm{NH}_{4}^{+}\right)$increases from 0.0015 to about $0.020 \mathrm{~h}^{-1}$. In the calculations of $\mathrm{V}\left(\mathrm{NH}_{4}^{+}\right)$, we have considered that ambient $\mathrm{NH}_{4}^{+}$was 0 when the analysis indicated a value $<0.05$ umole in the nitrate-depleted layer. As a result, the y-intercept of the curve (Fig. 6) is close to $0 . \mathrm{V}\left(\mathrm{NH}_{4}^{+}\right)$nevertheless

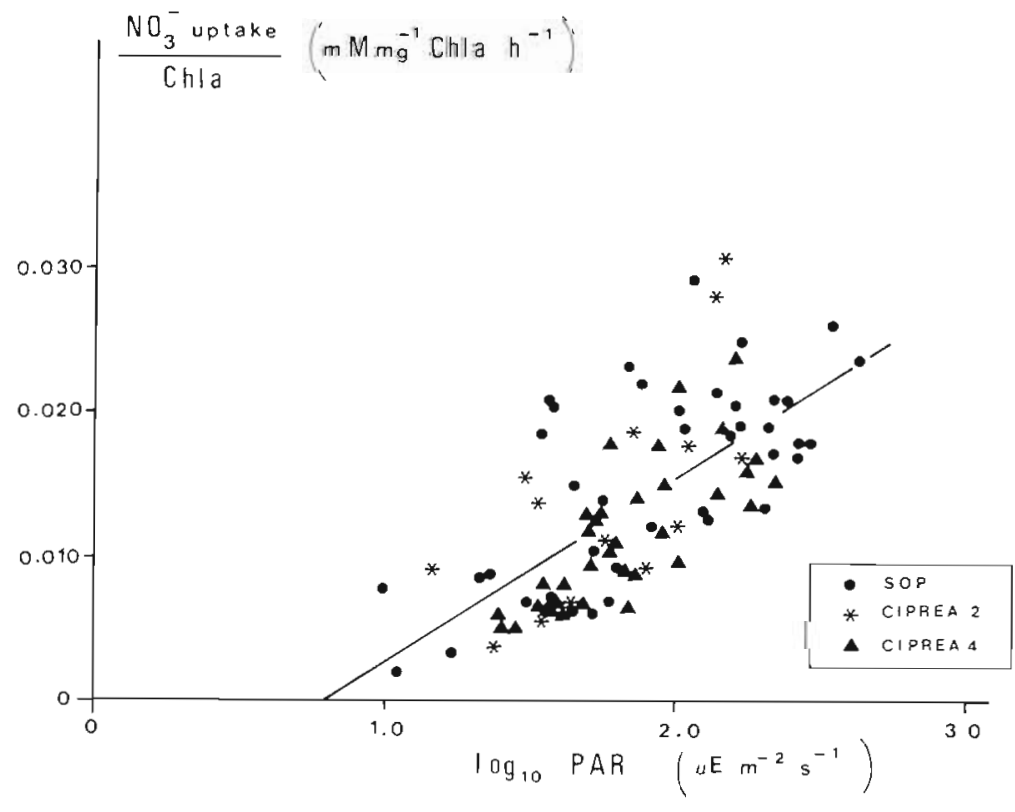

Fig. 4. Nitrate uptake index (mole $\mathrm{g}^{-1} \mathrm{Chla}^{-1}$ )

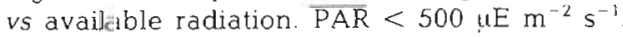
The regression line computed with all data has the following equation:

$$
\begin{gathered}
\frac{\rho\left(\mathrm{NO}_{3}^{-}\right)}{\mathrm{Chla}}=0.0128 \log _{10} \overline{\mathrm{PAR}}-0.0101 \\
(\mathrm{r}=0.68, \mathrm{df}=91)
\end{gathered}
$$




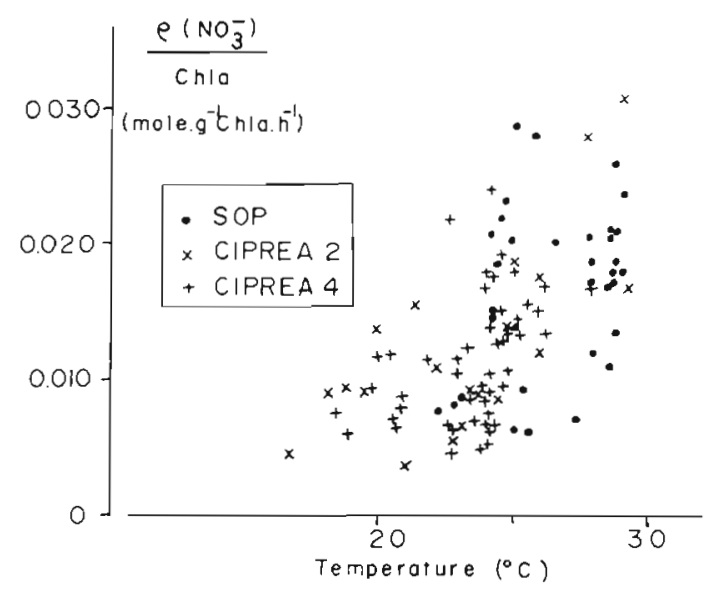

Fig. 5. Nitrate uptake index (mole $\mathrm{g}^{-1} \mathrm{Chla} \mathrm{h}^{-1}$ ) vs in situ

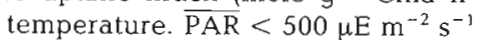

may be slightly under-estimated for the lowest ${ }^{15} \mathrm{~N}$ enrichments if the actual ambient $\mathrm{NH}_{4}^{+}$concentration is $>0$ but $<0.05 \mu$ mole (see discussion of Eppley et al. 1977). However, our results suggest that $\mathrm{V}\left(\mathrm{NH}_{4}^{+}\right)$varies with ${ }^{15} \mathrm{NH}_{4}^{+}$over a wide range, probably about one order of magnitude.

The effect of ${ }^{15} \mathrm{NH}_{4}^{+}$enrichment is also clearly evidenced on vertical profiles of $\rho\left(\mathrm{NH}_{4}^{+}\right)$from surface to the bottom of the euphotic layer. For example, samples collected at Stns 2 and 7 (SOP cruise) were enriched with 0.09 and 3.57 mmole $\mathrm{NH}_{4}^{+} \mathrm{m}^{-3}$ respectively. The ammonium uptake rates at Stn 7 are about 4 -fold greater than those at Stn 2 (Fig. 7). Like carbon fixation and nitrate uptake, $\rho\left(\mathrm{NH}_{4}^{+}\right)$seems to be coupled to the chlorophyll biomass (Fig. 7). The maximum value of $\rho$

Table 5. Variations of the nitrate uptake index with $\overline{\mathrm{PAR}}$ in the mixed layer. Ambient $\mathrm{NO}_{3}^{-}<0.1$ umole. SOP cruise data

\begin{tabular}{|c|c|c|c|c|}
\hline $\begin{array}{l}\text { Station } \\
\text { no. }\end{array}$ & $\begin{array}{l}\text { Depth } \\
\text { (m) }\end{array}$ & $\begin{array}{c}\overline{\mathrm{PAR}} \\
\left(\mu \mathrm{E} \mathrm{m}^{-2} \mathrm{~s}^{-1}\right)\end{array}$ & $\begin{array}{c}\top \\
\left({ }^{\circ} \mathrm{C}\right)\end{array}$ & 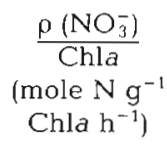 \\
\hline 3 & $\begin{array}{l}20 \\
30\end{array}$ & $\begin{array}{l}166 \\
113\end{array}$ & $\begin{array}{l}28.6 \\
28.0\end{array}$ & $\begin{array}{l}0.0206 \\
0.0173\end{array}$ \\
\hline 5 & $\begin{array}{l}10 \\
15 \\
20\end{array}$ & $\begin{array}{l}343 \\
267 \\
214\end{array}$ & $\begin{array}{l}28.7 \\
28.7 \\
28.7\end{array}$ & $\begin{array}{l}0.0260 \\
0.0180 \\
0.0173\end{array}$ \\
\hline 8 & $\begin{array}{l}10 \\
20\end{array}$ & $\begin{array}{l}284 \\
195\end{array}$ & $\begin{array}{l}29.0 \\
28.8\end{array}$ & $\begin{array}{l}0.0180 \\
0.0136\end{array}$ \\
\hline 10 & $\begin{array}{r}5 \\
15 \\
25\end{array}$ & $\begin{array}{l}424 \\
212 \\
127\end{array}$ & $\begin{array}{l}29.1 \\
28.8 \\
28.8\end{array}$ & $\begin{array}{l}0.0238 \\
0.0211 \\
0.0130\end{array}$ \\
\hline 13 & $\begin{array}{l}15 \\
25\end{array}$ & $\begin{array}{l}208 \\
128\end{array}$ & $\begin{array}{l}28.6 \\
28.6\end{array}$ & $\begin{array}{l}0.0172 \\
0.0111\end{array}$ \\
\hline
\end{tabular}

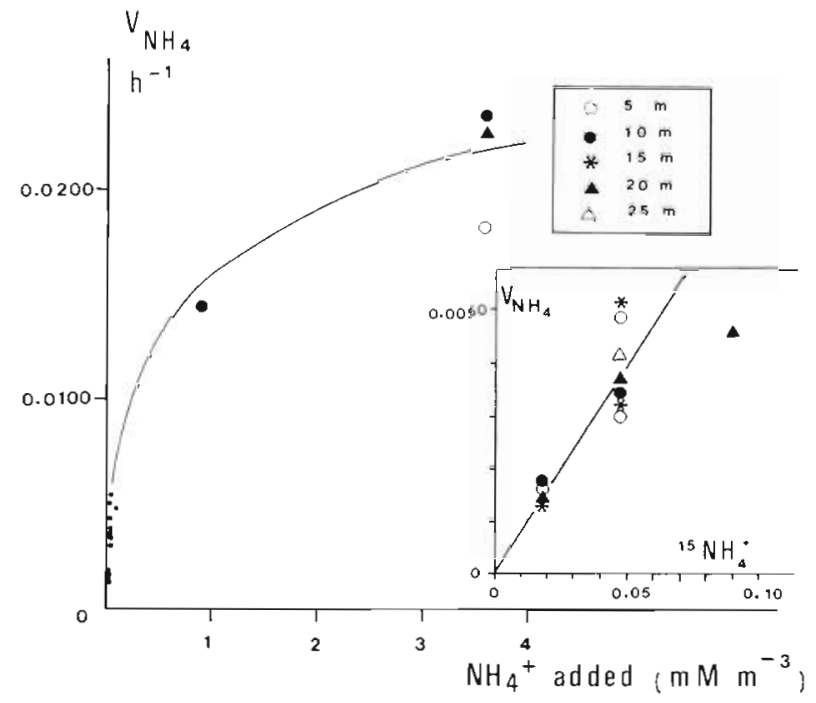

Fig. 6. Specific ammonium uptake rate $\mathrm{V}\left(\mathrm{NH}_{4}^{+}\right)\left(\mathrm{h}^{-1}\right)$ as a function of ${ }^{15} \mathrm{~N}-\mathrm{NH}_{A}^{+}$added to the sample (mmole $\mathrm{m}^{-3}$ ). Data from 7 stations, SOP and CIPREA 2 cruises. Chla $=[0.08-$ $0.12] \mathrm{mg} \mathrm{m}^{-3} \cdot \overline{\mathrm{PAR}}=[160-490] \mu \mathrm{E} \mathrm{m}^{-2} \mathrm{~s}^{-1}$. Ambient $\mathrm{NO}_{3}^{-}$ $<0.05 \mu$ mole. Ambient $\mathrm{NH}_{4}^{+}$generally $<0.05 \mu$ mole and considered as zero in the uptake calculations

$\left(\mathrm{NH}_{4}^{+}\right)$would be at the level of or just above the chlorophyll maximum.

Among the 60 samples (8 stations) with in situ $\mathrm{NH}_{4}^{+}$ uptake measurements considered here, only 2 contained more than 0.1 umole of natural ammonium. $\mathrm{V}\left(\mathrm{NH}_{4}^{+}\right)$estimate was then higher in both these samples, which is an indication of the ammonium uptake enhancement when $\mathrm{NH}_{4}^{+}$becomes detectable in the water. However, this result based upon only 2 data is not really conclusive.

One station with urea as a tracer (ambient urea $<0.05 \mu$ mole) showed that urea uptake rate seems of the same order of magnitude as expected for $\mathrm{NH}_{4}^{+}$ uptake with a similar ${ }^{15} \mathrm{~N}$ enrichment.

The light effect upon ammonium uptake within the euphotic layer is not well evidenced with our data. However, $\rho\left(\mathrm{NH}_{4}^{+}\right)$seems to decrease at depth for a constant ${ }^{15} \mathrm{~N}$ addition (Fig. 7). The ammonium uptake index (mole $\mathrm{NH}_{4}^{+} \mathrm{g}^{-1} \mathrm{Chl} a \mathrm{~h}^{-1}$ ) was often observed maximum at subsurface, like the nitrate uptake index.

\section{Size fractionation}

Several size fractionation experiments were performed with water sampled in the chlorophyll maximum at the top of the nitracline and incubated on deck under simulated in situ conditions. Results indicate that phytoplankton of the $<3 \mu \mathrm{m}$ fractions presents a lower affinity for nitrate than larger cells contained in the $<35 \mu \mathrm{m}$ and $<200 \mu \mathrm{m}$ fractions (Fig. 8 , 


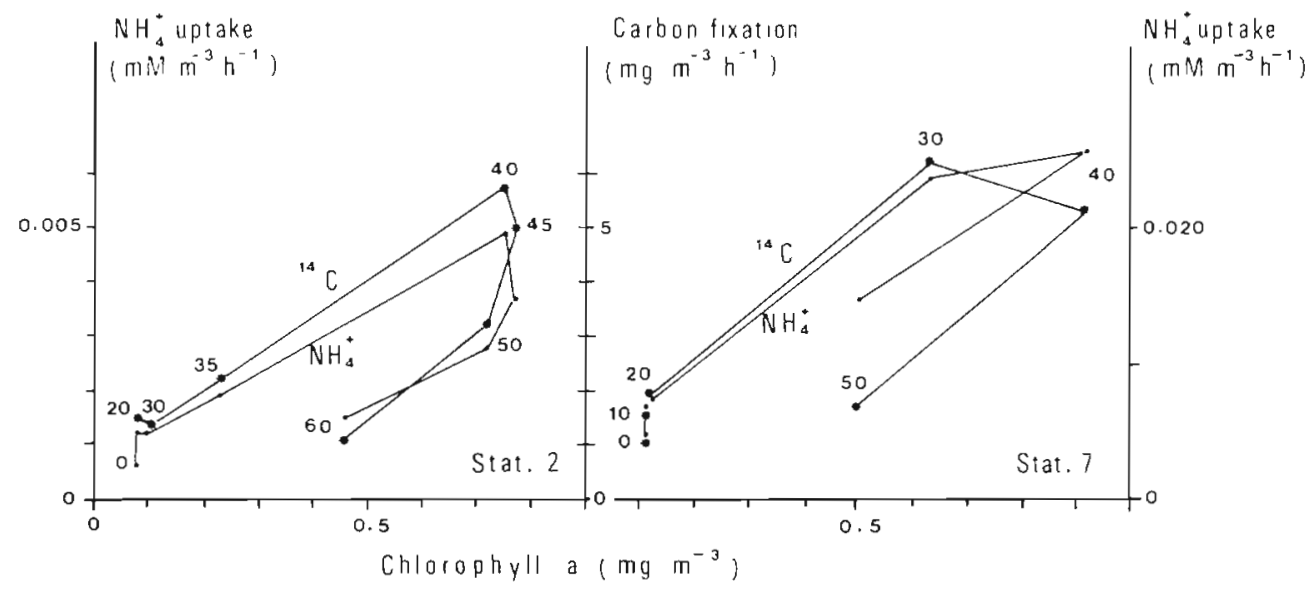

Fig. $7 \quad \rho\left(\mathrm{NH}_{4}^{+}\right) \quad$ (mmole $\left.\mathrm{m}^{-3} \mathrm{~h}^{-1}\right)$ and $\rho \mathrm{C}\left(\mathrm{mg} \mathrm{m}^{-3}\right.$ $\mathrm{h}^{-1}$ ) vs Chla (mg m ) ${ }^{15} \mathrm{NH}_{4}^{+}$added $=0.09$ and 3.57 mmole $^{-3}$, Stn 2 and 7 respectively. Sampling and incubation depth indicated near each point

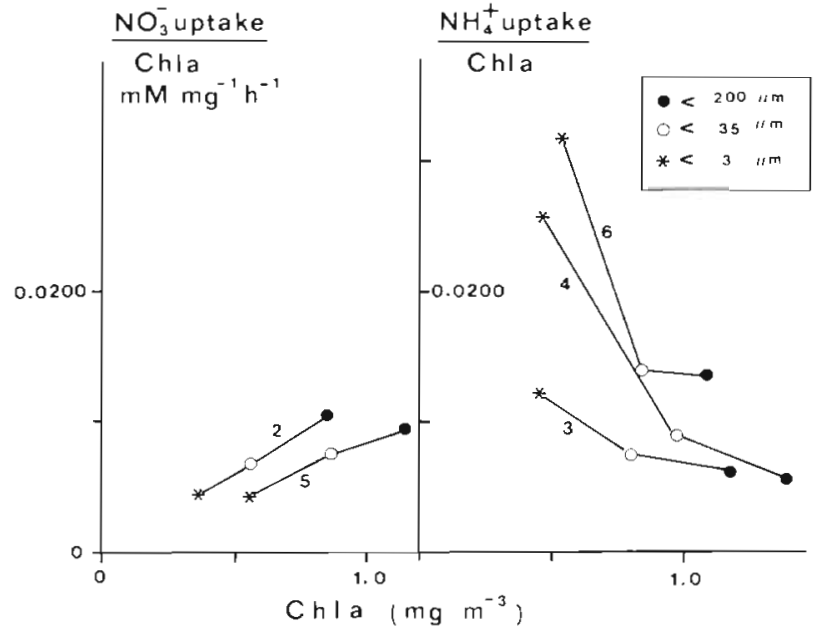

Fig. 8. Nitrate uptake index and ammonium uptake index (mole $\mathrm{N} \mathrm{g}^{-1}$ Chla $\mathrm{h}^{-1}$ ) vs Chla $\left(\mathrm{mg} \mathrm{m}^{-3}\right.$ ). Size fractionation experiments with prescreened subsamples $(<200 \mu \mathrm{m},<35$ $\mu \mathrm{m},<3 \mu \mathrm{m})$

Table 6). Inversely, the same experiments carried out in the same conditions with $\mathrm{NH}_{4}^{+}$as a tracer lead to an exactly opposite observation: the ammonium uptake index seems higher in the fraction which contains only the $<3 \mu \mathrm{m}$ phytoplankton cells than in the other ones (Fig. 8)

Table 6. Ambient and added nitrate and ammonium concentrations (mmole $\mathrm{m}^{-3}$ ) and PAR received by samples $\left(\mu \mathrm{E} \mathrm{m}^{-2} \mathrm{~s}^{-1}\right)$. Flve $\mathrm{h}$ incubations. Sampling depth: $40 \mathrm{~m}$. SOP cruise data

\begin{tabular}{|cccccc|}
\hline $\begin{array}{c}\text { Station } \\
\text { no. }\end{array}$ & $\begin{array}{c}\text { Ambient } \\
\mathrm{NO}_{3}^{-}\end{array}$ & $\begin{array}{c}\text { Ambient } \\
\mathrm{NH}_{4}^{+}\end{array}$ & $\begin{array}{c}\text { Added } \\
\mathrm{NO}_{3}^{-}\end{array}$ & $\begin{array}{c}\text { Added } \\
\mathrm{NH}_{4}^{+}\end{array}$ & $\overline{\mathrm{PAR}}$ \\
\hline 2 & 0.80 & 0.08 & 1.79 & - & 35.6 \\
3 & 1.97 & 0.05 & - & 0.09 & 35.3 \\
4 & 1.59 & 0.08 & - & 0.045 & 33.2 \\
5 & 1.49 & 0.02 & 0.89 & - & 34.6 \\
6 & 0.70 & 0.13 & - & 0.045 & 31.2 \\
& & & & & \\
\hline
\end{tabular}

\section{DISCUSSION}

In waters containing more than $0.1 \mu$ mole of nitrate, the nitrate uptake rate $\rho\left(\mathrm{NO}_{3}^{-}\right)$is directly related to the chlorophyll a concentration (Fig. 2). This result was obtained under environmental conditions as good as possible for using the ${ }^{15} \mathrm{~N}$ method in the open ocean: relatively high phytoplankton biomass (Chla $>0.2 \mathrm{mg}$ $\mathrm{m}^{-3}$ ) and nitrate concentration easily measurable. Therefore, at every depth of the nitracline, for one given PAR, new production primarily depends on Chla. Similarly, values integrated by surface unit show the same trend (Fig. 3).

Carbon fixation is also closely coupled to Chla (Le Bouteiller \& Herbland 1984). Consequently, $\rho\left(\mathrm{NO}_{3}^{-}\right)$is highly correlated to the carbon fixation $(r=0.89$, correlation coefficient calculated on the same set of samples as in Fig. 2).

Ambient $\mathrm{NO}_{3}^{-}$concentration ranged from 0.1 to 8.2 umoles in samples considered here (Table 3). However, the nitrate uptake index is not correlated to the nitrate concentration (Table 3) even if ${ }^{15} \mathrm{~N}$ enrichment is considered. Consequently, nitrate availability would be most often sufficient in these waters for achieving a nearly maximum $\rho\left(\mathrm{NO}_{3}^{-}\right)$.

By contrast, the effects of light supply are well evidenced (Fig. 4), although more or less coupled with the temperature effects (Table 3, Fig. 5). Temperature is known to control a number of physiological processes and to set an upper limit on phytoplankton growth rate (Eppley 1972). Data reported by Kanda et al. (1985) suggest that temperature influences nitrate uptake at surface in the Pacific ocean. If we suppose a $Q_{10}$ close to 2 for the nitrate uptake rate (Eppley 1972, Glibert et al. 1982b, Raimbault 1984), variations of the nitrate uptake index reported here would be due in equal parts to both light and temperature (Fig. $4 \& 5$ ).

If new production $\rho\left(\mathrm{NO}_{3}^{-}\right)$and total production $\rho \mathrm{C}$ are both strongly related to the chlorophyll biomass, 
does the ratio new/total production also vary with Chla and with carbon fixation, as suggested by Eppley \& Peterson (1979), Harrison (1980) and Eppley (1981)? Comparison of the ratio $\rho \mathrm{C} / \rho\left(\mathrm{NO}_{3}^{-}\right)$with Chla (Fig. 9) shows that the higher values are obtained in chlorophyll-poor waters, either at surface in the mixed layer $\left(\mathrm{PAR}>200 \mu \mathrm{E} \mathrm{m} \mathrm{m}^{-2} \mathrm{~s}^{-1}\right)$ or below the Chl $a$ maximum (PAR $\left.<50 \mu \mathrm{E} \mathrm{m} \mathrm{m}^{-2} \mathrm{~s}^{-1}\right)$. Conversely, the lower values are observed within the chlorophyll maximum, whatever its depth may be. Exactly the same trend is seen when the ratio $\rho \mathrm{C} / \rho\left(\mathrm{NO}_{3}^{-}\right)$is compared to total production instead of Chla.

So, the share of new production in total production increases with the phytoplankton biomass, but not directly with the amount of nitrate or PAR. This result has required the use of 5 different methods, each of them inevitably imperfect $\left({ }^{14} \mathrm{C}\right.$ and ${ }^{15} \mathrm{~N}-\mathrm{NO}_{3}^{-}$uptake, particulate nitrogen and chlorophyll concentration, ambient nitrate). For example, the use of Gelman filters for PON measurements probably has under-estimated nitrate uptake by comparison to carbon fixation measurements with Sartorius filters. Isotope dilution resulting from $\mathrm{NH}_{4}^{+}$remineralization during incubation was not determined (Harrison 1978, Glibert et al. 1982a, Garside 1984). In the same way, the possible effect of multiple simultaneous nitrogen sources was not considered in the calculations (Collos pers. comm.) Excretion of dissolved organic nitrogen was not estimated (Collos \& Slawyk 1983, Laws 1984). All these biases would yield under-estimates of $\rho\left(\mathrm{NO}_{3}^{-}\right)$in oligotrophic waters for small tracer additions, whereas ${ }^{15} \mathrm{~N}$ enrichments by contrast would tend to enhance uptake rates in such waters (Harrison 1983). However, the ratio $\rho \mathrm{C} / \rho\left(\mathrm{NO}_{3}^{-}\right)$also decreases when Chla increases in nitrate rich waters where artefacts are minimized. So, the order of magnitude and the main tendency may be reasonably considered as close to reality: the rate of new production by nitrate uptake would be effectively much higher in chlorophyll rich waters than in poor ones.

Assuming that in this ecosystem, growth rate of phytoplankton is close to the maximum growth rate, the uptake ratio $\mathrm{C} / \mathrm{N}$ may be considered as close to the classical Redfield composition ratio $\mathrm{C} / \mathrm{N}=6.6$ (Goldman et al. 1979). Then the phytoplankton nitrogen requirements can be calculated from carbon fixation data. For one of the most oligatrophic stations (Stn 140 , Chla $=14.2 \mathrm{mg} \mathrm{m}^{-2}, \rho \mathrm{C}=90 \mathrm{mg} \mathrm{m}^{-2} \mathrm{~h}^{-1}, \rho\left(\mathrm{NO}_{3}^{-}\right)=$ 0.11 mmole $\mathrm{m}^{-2} \mathrm{~h}^{-1}$ ), about $10 \%$ of the nitrogen needs estimated in the euphotic layer ( $76 \mathrm{~m}$ depth) are satisfied by nitrate uptake. For one of the richest stations (Stn 3, SOP cruise, Chla $=26 \mathrm{mg} \mathrm{m}^{-2}, \rho \mathrm{C}=157 \mathrm{mg}$ $\left.\mathrm{m}^{-2} \mathrm{~h}^{-1}, \rho\left(\mathrm{NO}_{3}^{-}\right)=0.38 \mathrm{mmole} \mathrm{m}^{-2} \mathrm{~h}^{-1}\right), \rho\left(\mathrm{NO}_{3}^{-}\right)$ represents about $19 \%$ of the nitrogen requirements. These values are of the order of magnitude expected: in their review, Eppley \& Peterson (1979) reported that new production is nearly $18 \%$ of total production on the average in waters of equatorial divergence.

Although more or less biased by the presence of nonphytoplanktonic PON in samples (Dugdale \& Goering 1967), $\mathrm{V}\left(\mathrm{NO}_{3}^{-}\right)$can be calculated for comparison with other values reported in the literature. In the chlorophyll maximum layer, when Chla $>0.5 \mathrm{mg} \mathrm{m}^{-3}$, $\mathrm{V}\left(\mathrm{NO}_{3}^{-}\right)=0.02 \mathrm{~h}^{-1}$. This value is high since it is of the order of magnitude often observed in the northwest Africa upwelling area (Maclsaac et al. 1974, Slawyk et al. 1976, Harrison \& Davis 1977, Nelson \& Conway 1979) and off Peru (Maclsaac \& Dugdale 1972, Maclsaac et al. 1985). The corresponding flux of nitrate however satisfies only about $25 \%$ of the estimated nitrogen needs. Consequently, one may reasonably conclude that, although roughly estimated, the share of new production in total production probably never predominates in this region, even when surface waters are nitrate rich, as for example during CIPREA 4 cruise.

When extrapolated for $\mathrm{NO}_{3}^{-}<0.1 \mu$ mole, the regression line calculated between $\rho\left(\mathrm{NO}_{3}^{-}\right)$and Chla within the nitracline suggests that only low, if any, nitrate uptake occurs in the nitrate-depleted mixed layer (Fig. 2). However, from 23 measurements of $\rho\left(\mathrm{NO}_{3}^{-}\right)$performed in the mixed layer with ${ }^{15} \mathrm{NO}_{3}^{-}$ additions exceeding 0.2 mmole $\mathrm{m}^{-3}$, a mean $\rho$ ( $\mathrm{NO}_{3}^{-}$) of 0.0016 mmole $\mathrm{m}^{-3} \mathrm{~h}^{-1}$ was achieved (Table 4 ). This value is high since 2 or 3 -fold greater than those recently reported by Kanda et al. (1985) in the eastern tropical Pacific for similar chlorophyll concentrations and water temperature. Experimental conditions were quite different: Kanda et al. (1985) used 2 l flasks incubated for $3 \mathrm{~h}$ under a constant illumination of 270 $\mu E \mathrm{~m}^{-2} \mathrm{~s}^{-1}$ whereas our incubations were carried out in situ from sunrise to sunset in 6 or 111 bottles. The productivity indexes calculated by Kanda et al. (1985) for the same samples ranged from 3.0 to $5.1 \mathrm{~g} \mathrm{C} \mathrm{g}^{-1}$ Chla $\mathrm{h}^{-1}$. These values are much lower than those calculated from Table 4 data. Hence, the natural assemblages of phytoplankton could have very different physiological responses according to the experimental proceedings and from one oceanic region to another. For example, Laws et al. (1984) reported productivity indexes ranging from 7.4 to $15.5 \mathrm{~g} \mathrm{C} \mathrm{g}^{-1} \mathrm{Chla}$ $\mathrm{h}^{-1}$ in oligotrophic waters off Hawaii, at a position situated near one of the stations occupied by Kanda et al. (1985).

However that may be, the ${ }^{15} \mathrm{~N}$ method, when applied with high ${ }^{15} \mathrm{~N}$ additions in nitrate poor waters, provides only a potential maximum nitrate uptake rate, but the accurate nitrate flux in the mixed layer remains unknown, although suspected by other methods (Klein \& Coste 1984, Garside 1985). 
Undoubtedly, one major problem using the ${ }^{15} \mathrm{~N}$ method in the field consists in estimating the actual nitrate or ammonium uptake rate in oligotrophic waters (McCarthy 1980, Goldman \& Glibert 1983). When ambient nitrate or ammonium concentration is close to or below the level of analytical detection, a true trace enrichment of the substrate is strictly impossible (Goldman 1980, McCarthy 1980, Glibert \& Goldman 1981). The addition of labelled substrate inevitably changes the nutrient availability and hence the uptake rate (Dugdale \& Goering 1967. Eppley et al. 1977. Harrison 1983). As reported above, our results of ammonium uptake rate depend directly on the amount of tracer added. Ambient $\mathrm{NH}_{4}^{+}$concentration was generally lower than $0.05 \mu$ mole, which is the common situation in the open ocean.

However, an important item of information obtained for a constant ${ }^{15} \mathrm{NH}_{4}^{+}$addition is that the ammonium uptake index seems to be related to the available radiation. During CIPREA 4 cruise, the amplitude of diel variations of chlorophyll $a$ and the rate of chlorophyll synthesis were both maximum between 15 and $30 \mathrm{~m}$ and decreased downwards (Le Bouteiller \& Herbland 1982). Phosphate uptake was also observed maximum at subsurface during SOP and CIPREA 2 cruises and decreased at depth (Herbland 1984). Growth rate was estimated higher in the mixed layer than in the chlorophyl maximum (Herbland \& Le Bouteiller 1983). The productivity index systematically presented a peak at 5 to $15 \mathrm{~m}$ (analysis of 31 profiles of $\rho$ C/Chla from SOP, CIPREA 2, CIPREA 4 and CIPREA 5 cruises), whether nitrate is abundant at surface or totally undetectable, and was strongly related to the available radiation (Le Bouteiller \& Herbland 1984). We have seen above that the nitrate uptake index was also significantly correlated to PAR (Fig. 4). So, various indexes of phytoplankton metabolic activity and growth rate, such as photosynthesis, chlorophyll a synthesis, phosphate, nitrate and ammonium uptake, appear to be closely coupled to the amount of available light but not directly to nitrate or chlorophyll a concentration. If all these processes primarily depend on PAR, it means that there would exist a vertical gradient of the average growth rate of phytoplankton, mainly controlled by PAR but also probably by temperature. A striking point to be noted is that this growth rate vertical gradient would exist not only in the nitrate rich layer of the euphotic zone, but also in the mixed layer. Although the mechanisms of phytoplankton production and the structure of the food web in the nitracline are probably rather different from those in the mixed layer, the various methods used here for estimating this production do not permit showing any clear difference of production efficiency between the 2 layers. If confirmed by other studies, this result signifies that

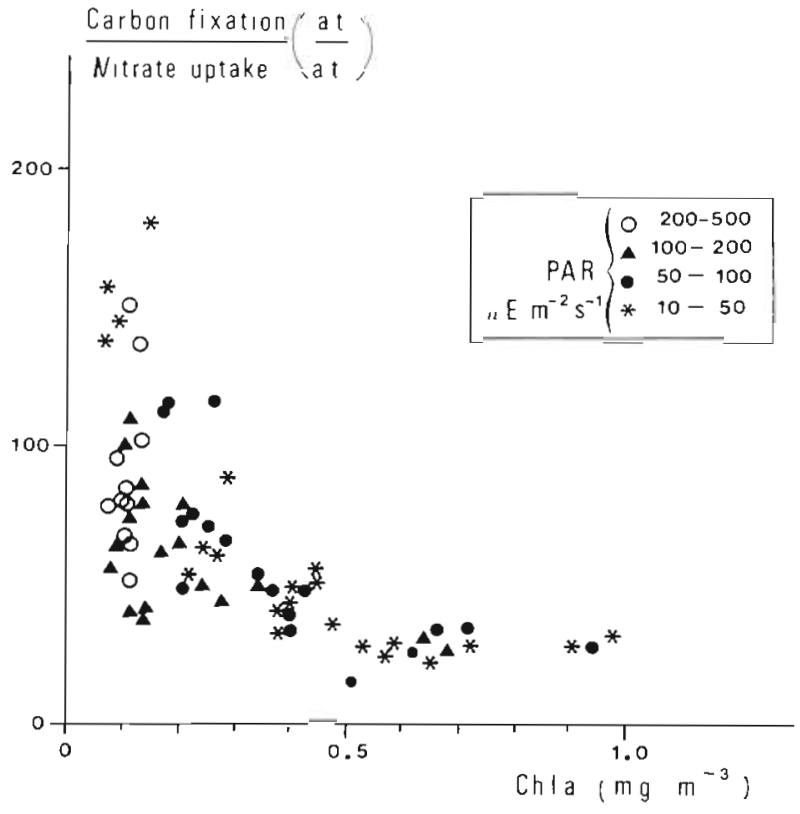

Fig. 9. $\rho \mathrm{C} / \rho\left(\mathrm{NO}_{3}^{-}\right)$(at/at) vs Chla $\left(\mathrm{mg} \mathrm{m}^{-3}\right)$ for several ranges

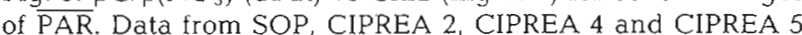
cruises

both light and temperature would be the major factors controlling the phytoplankton growth rate from the top to the bottom of the euphotic layer.

If growth rate seems maximum in the well-lighted surface layer, by contrast the share of new production in total production is very low in oligotrophic waters and maximum in the chlorophyll maximum (Fig.9). This means that the phytoplankton affinity for nitrate changes from chlorophyll poor waters to rich ones. The size fractionations presented here have shown that phytoplankton of the $<3 \mu \mathrm{m}$ fraction would assimilate preferentially ammonium whereas nitrate would be taken up by the larger cells (Fig. 8). The same trend has been observed on the $<1 \mu \mathrm{m}$ fraction compared to the total fraction by Harrison et al. (1983) in the Middle Atlantic Bight. These observations have a major significance when compared to the size distribution of phytoplankton biomass. As shown previously, the percentage of $>1 \mu \mathrm{m}$ and $>3 \mu \mathrm{m}$ Chla increases with total chlorophyll concentration in this region (Herbland \& Le Bouteiller 1981). The higher the chlorophyll concentration, the more relatively numerous are the $>3 \mu \mathrm{m}$ phytoplankton organisms. Moreover, Herbland et al. (1985) reported that in the nitrate-depleted layer of the Equatorial Atlantic ocean, $71 \%$ of the total Chla on the average belong to the $<1$ um size fraction. As soon as $\mathrm{NO}_{3} \geqslant 0.1 \mu$ mole in sea-water, this percentage decreases under $50 \%$ : the bulk of Chla is then contained in $>1 \mu \mathrm{m}$ particles.

Hence, ammonium would be mainly taken up by picoplankton which dominates in the mixed layer but 
represents also a considerable percentage of the total phytoplankton within the nitracline. Nitrate by contrast would be assimilated preferentially by larger cells which are specially numerous in the chlorophyll maximum.

We have seen above that nitrate assimilation represents at best $25 \%$ of the nitrogen needs. Hence, from 75 to nearly $100 \%$ of the nitrogen requirements would be satisfied by other forms of nitrogen than nitrate. Though barely detectable, ammonium is known to be the major source of nitrogen in oligotrophic waters (Dugdale \& Goering 1967, Maclsaac \& Dugdale 1972). The supply of ammonium excreted by microzooplankton and bacteria (Harrison 1980) would be sufficient for phytoplankton to maintain nearly maximum growth rates (Goldman et al. 1979, McCarthy \& Goldman 1979, Glibert et al. 1982a). Other nitrogen compounds, though less important, also have been considered as useful nitrogen sources: $\mathrm{N}_{2}$ is fixed by cyanobacteria and Oscillatoria (Carpenter 1983). Urea (McCarthy 1972, Herbland 1976, present study) and other dissolved organic nitrogen forms are assimilated by phytoplankton (Paul 1983, Jackson \& Williams 1985). During CIPREA 1 cruise (Sep 1978), from 6 to $10 \mu$ moles of dissolved organic nitrogen were measured in the mixed layer at the position $\left(0^{\circ}, 4^{\circ} \mathrm{W}\right)$ (Voituriez 1980). However, several recent works have demonstrated that in oligotrophic waters, ammonium regenerated in situ accounted for virtually all the primary production requirements (Caperon et al 1979. Harrison 1980, Glibert et al. 1982a). So, one major point to be stressed is the fact that schematically, not only in the mixed layer but also within the nitracline, the principal process of nitrogenous nutrition of phytoplankton in this area would be ammonium uptake by picoplankton.

\section{CONCLUSION}

In the open equatorial Atlantic ocean, at more than 300 nautical miles off Africa, far from all island mass effect (Dandonneau \& Charpy 1985), a detailed study of primary production has shown that the chlorophyll a concentration provides nearly all the information required not only to predict primary production in term of carbon, but also to estimate new production by nitrate uptake for a mean incident radiation. Within the nitracline, nitrate uptake increases not directly because of the nitrate abundance but because of higher Chla concentration: $\rho\left(\mathrm{NO}_{3}^{-}\right)$is maximum at depth of Chla maximum and not in the nitrate richest waters (Fig. 1). Hence, depth distribution of chlorophyll a would be the first parameter to be known accurately for modelling global fluxes of carbon and nitrogen in the open ocean.
Although important day-to-day variations of biomass and production occurred according to rapid changes of the nitracline depth due to the south-north oscillations of the equatorial current system (Herbland \& Le Bouteiller 1982), the ratio of new to total production was always low, less than 0.25 , and directly related to Chla, not to $\mathrm{NO}_{3}^{-}$concentration. Recently, Platt \& Harrison (1985) used results obtained on the continental shelf of the Middle Atlantic Bight by Harrison et al. (1983) to compute new production from $\mathrm{NO}_{3}^{-}$data in the Sargasso Sea. The present study suggests that such an extrapolation would be impossible in the eastern equatorial Atlantic ocean.

If regenerated production widely predominates at every depth of the photic zone, even in the presence of nitrate, a close coupling between remineralization, production and consumption is necessarily achieved to maintain biomass distributions (Walsh 1976, Goldman et al. 1979, Le Borgne 1981, Voituriez \& Herbland 1984). If furthermore several indexes of production efficiency and growth rate appear to not depend directly on ambient nitrate, then not surprisingly growth rate would be mainly controlled by both light and temperature. Production at every depth would vary primarily with both biomass and growth rate.

Acknowledgements. ${ }^{15} \mathrm{~N}$ samples were analyzed in the mass spectrometer implemented by G. Slawyk at Marseille, France. I thank A. Herbland and G. Slawyk for constructive comments. This work was supported by ORSTOM, Institut Français de Recherche scientifique pour le Développement en Coopération.

\section{LITERATURE CITED}

Caperon, J., Schell, D., Hirota, J., Laws, E. (1979). Ammonium excretion rates in Kaneohe Bay, Hawaii, measured by a ${ }^{15} \mathrm{~N}$ isotope dilution technique. Mar. Biol. 54: 33-40

Carpenter, E. J. (1983). Nitrogen fixation by marine Oscillatoria (Trichodesmium) in the world's oceans In: Carpenter, E. J., Capone, D. G. (ed.) Nitrogen in the marine environment. Academic Press, New York, p. 65-103

Collos, Y., Slawyk, G. (1983). Ammonium and nitrate in the tropical and equatorial Atlantic: relations with the primary nitrite maximum. Mar. Biol. Lett. 4: 295-308

Dandonneau, Y., Charpy, L. (1985). An empirical approach to the island mass effect in the south tropical Pacific based on sea surface chlorophyll concentrations. Deep Sea Res. 32: $707-721$

Dugdale, R. C. (1967). Nutrient limitation in the sea: dynamics, identification, and significance. Limnol. Oceanogr. 12: 685-695

Dugdale, R. C., Goering, J. J. (1967). Uptake of new and regenerated forms of nitrogen in primary productivity. Limnol. Oceanogr. 12: 196-206

Eppley, R. W. (1972). Temperature and phytoplankton growth in the sea. Fish. Bull. U.S. 70: 1063-1085

Eppley, R. W. (1981). Autotrophic production of particulate 
matter In: Longhurst, A. R. (ed.) Analysis of marine ecosystems. Academic Press, London, p. 343-361

Eppley, R. W. Peterson, B. J. (1979). Particulate organic matter flux and planktonic new production in the deep ocean. Nature, Lond. 282: 677-680

Eppley, R. W., Sharp, J. H., Renger, E. H., Perry, M. J., Harrison, W. G. (1977). Nitrogen assimilation by phytoplankton and other microorganisms in the surface waters of the Central North Pacific Ocean. Mar. Biol. 39: 111-120

Eppley, R. W., Renger, E. H., Harrison, W. G., Cullen, J. J (1979). Ammonium distribution in southern California coastal waters and its role in the growth of phytoplankton. Limnol. Oceanogr. 24: 495-509

Eppley, R. W., Renger, E. H., Betzer, P. R. (1983). The residence time of particulate organic carbon in the surface layer of the ocean. Deep Sea Res. 30: 311-323

Garside, C. (1984). Apparent ${ }^{15} \mathrm{~N}$ uptake kinetics resulting from remineralization. Limnol. Oceanogr. 29: 204-210

Garside, C. (1985). The vertical distribution of nitrate in open ocean surface water. Deep Sea Res. 32: 723-732

Glibert, P. M., Goldman, J. C. (1981). Rapid ammonium uptake by marine phytoplankton. Mar. Biol. Lett. 2: 25-31

Glibert, P. M., Lipschultz, F., McCarthy, J. J., Altabet, M. A. (1982a). Isotope dilution models of uptake and remineralization of ammonium by marine phytoplankton. Limnol. Oceanogr. 27: 639-650

Glibert, P. M., Goldman, J. C., Carpenter, E. J. (1982b). Seasonal variations in the utilization of ammonium and nitrate by phytoplankton in Vineyard Sound, Massachusetts. Mar Biol. 70: 237-249

Glover, H. E., Phinney, D. A., Yentsch, C. S. (1985). Photosynthetic characteristics of picoplankton compared with those of larger phytoplankton populations, in various water masses in the Gulf of Maine. Biol. Oceanogr. 3: 223-247

Goldman, J. C. (1980). Physiological processes, nutrient availability, and the concept of relative growth rate in marine phytoplankton ecology. In: Falkowsky, P. G. (ed.). Primary productivity in the sea. Plenum Press, New York, p. $179-193$

Goldman, J. C., Glibert, P. M. (1983). Kinetics of inorganic nitrogen uptake by phytoplankton. In: Carpenter, E. J., Capone, D. G. (ed.) Nitrogen in the marine environment. Academic Press, New York, p. 233-274

Goldman, J. C., McCarthy, J. J., Peavey, D. G. (1979). Growth rate influence on the chemical composition of phytoplankton in oceanic waters. Nature, Lond. 279: 210-215

Harrison, P. J., Davis, C.O. (1977). Use of the perturbation technique to measure nutrient uptake rates for natural phytoplankton populations. Deep Sea Res. 24: 247-255

Harrison, W. G. (1978). Experimental measurements of nitrogen remineralization in coastal waters. Limnol. Oceanogr. 26: $684-694$

Harrison, W. G. (1980). Nutrient regeneration and primary production in the sea. In: Falkowski, P. G. (ed.) Primary productivity in the sea. Plenum Press, New York, p. $433-460$

Harrison, W. G. (1983). Use of isotopes. In: Carpenter. E. J., Capone, D. G. (ed.). Nitrogen in the marine environment. Academic Press, New York, p. 763-807

Harrison, W. G., Douglas, D., Falkowski, P., Rowe, G., Vidal, J. (1983). Summer nutrient dynamics of the Middle Atlantic Bight: nitrogen uptake and regeneration. J. Plankton Res. 5: 539-556

Herbland, A. (1976). In situ utilization of urea in the euphotic zone of the tropical Atlantic. J. exp. mar. Biol. Ecol. 21 $269-277$
Herbland, A. (1984). Phosphate uptake in the euphotic layer of the equatorial Atlantic ocean. Methodological observations and ecological significance. Oceanogr Trop. 19 $25-40$

Herbland, A., Le Bouteiller, A. (1981). The size distribution of phytoplankton and particulate organic matter in the Equatorial Atlantic Ocean: Importance of ultraseston and consequences. J. Plankton Res. 3: 659-673

Herbland, A., Le Bouteiller, A. (1982). The meanders of equatorial currents in the Atlantic Ocean: influence on the biological processes. Oceanogr Trop. 17: 15-25

Herbland, A., Le Bouteiller, A. (1983). Dynamique du phytoplancton et matière organique particulaire dans la zone euphotique de l'Atlantique Equatorial. Mar. Biol. 72: 265-276

Herbland, A., Le Bouteiller, A., Raimbault, P. (1985). Size structure of phytoplankton biomass in the equatorial Atlantic ocean. Deep Sea Res. 32: 819-836

Herbland, A., Voituriez, B. (1979). Hydrological structure analysis for estimating the primary production in the tropical Atlantic Ocean. J. mar. Res. 37: 87-101

Jackson, G. A., Williams, P. M. (1985). Importance of dissolved organic nitrogen and phosphorus to biological nutrient cycling. Deep Sea Res. 32: 223-235

Jitts, H. R., Morel, A., Saijo, Y (1976). The relation of oceanic production to available photosynthetic irradiance. Aust. J. mar. Freshwat. Res. 27: 441-454

Kanda, J., Saino, T., Hattori, A. (1985). Nitrogen uptake by natural populations of phytoplankton and primary production in the Pacific Ocean: regional variability of uptake capacity. Limnol. Oceanogr. 30: 987-999

Klein, P., Coste, B. (1984). Effects of wind-stress variability on nutrient transport into the mixed layer. Deep Sea Res. 31: $21-37$

Laws, E. A. (1984). Isotope dilution models and the mystery of the vanishing ${ }^{15} \mathrm{~N}$. Limnol. Oceanogr. 19: 379-386

Laws, E. A., Redalje, D. G., Haas, L. W., Bienfang, P. K., Eppley, R. W., Harrison, W. G., Karl, D. M., Marra, J. (1984). High phytoplankton growth and production rates in oligotrophic Hawaiian coastal waters. Limnol. Oceanogr. 29: 1161-1169

Le Borgne, R. (1981). Relationships between the hydrological structure, chlorophyll and zooplankton biomasses in the Gulf of Guinea. J. Plankton Res. 3: 577-592

Le Bouteiller, A., Herbland, A. (1982). Diel variation of chlorophyll a as evidenced from a 13 day station in the equatorial Atlantic Ocean. Oceanologica Acta 5: 433-441

Le Bouteiller, A., Herbland, A. (1984). Carbon fixation and productivity index in relation to chlorophyll and light in the equatorial Atlantic Ocean. Oceanogr Trop. 19: $161-179$

Li, W. K.W. (1980). Temperature adaptation in phytoplankton: cellular and photosynthetic characteristics. In: Falkowski, P. G. (ed.). Primary productivity in the sea. Plenum Press, New York, p. 259-279

Li, W. K. W., Subba Rao, D. V., Harrison, W. G., Smith, J. C., Cullen, J. J., Irwin, B., Platt, T. (1983). Autotrophic picoplankton in the Tropical Ocean. Science 219: 292-295

Maclsaac, J. J., Dugdale, R. C. (1969). The kinetics of nitrate and ammonia uptake by natural populations of marine phytoplankton. Deep Sea Res. 16: 45-57

MacIsaac, J. J., Dugdale, R. C. (1972). Interactions of light and inorganic nitrogen in controlling nitrogen uptake in the sea. Deep Sea Res. 19: 209-232

Maclsãac, J. J., Dugdále, R. C., Slawryk, G. (1974). Nitrogen uptake in the northwest Africa upwelling area: results from the CINECA-Charcot II cruise. Téthys 6: 69-76 
Maclsaac, J. J., Dugdale, R. C., Barber, R. T., Blasco, D., Packard, T. T. (1985). Primary production cycle in an upwelling center. Deep Sea Res. 32: 503-529

McCarthy, J. J. (1972). The uptake of urea by natural populations of marine phytoplankton. Limnol. Oceanogr 17 738-748

McCarthy, J. J. (1980). Nitrogen. In: Morris I. (ed.) The physiological ecology of phytoplankton. Univ. California, Berkeley, p. 191-233

McCarthy, J. J., Goldman, J. C. (1979). Nitrogenous nutrition of marine phytoplankton in nutrient-depleted waters. Science 203: 670-672

McCarthy, J. J., Wynne, D., Berman, T (1982). The uptake of dissolved nitrogenous nutrients by Lake Kinneret (Israel) microplankton. Limnol. Oceanogr. 27: 673-680

Menzel, D. W., Corwin, N. (1965). The measurement of total phosphorus in seawater based on the liberation of organically bound fractions by persulfate oxydation. Limnol. Oceanogr 10: 280-282

Morel, A. (1978). Available, usable, and stored radiant energy in relation to marine photosynthesis. Deep Sea Res. 25: $673-688$

Nelson, D. M., Conway, H. L. (1979). Effects of the light regime on nutrient assimilation by phytoplankton in the Baja California and northwest Africa upwelling systems. J. mar. Res. 37: 301-318

Paul, J. H. (1983). Uptake of organic nitrogen. In: Carpenter, E. J., Capone, D. G. (ed.) Nitrogen in the marine environment. Academic Press, New York, p. 275-368

Pavlou, S. P., Friederich, G., Macisaac, J. J. (1974). Quantitative determination of total nitrogen and isotope enrichment in marine phytoplankton. Analyt. Biochem. 61: $12-24$

Platt, T., Harrison, W. G. (1985). Biogenic fluxes of carbon and oxygen in the ocean. Nature, Lond. 318: 55-58

Platt, T., Subba Rao, D. V., Irwin, B. (1983). Phostosynthesis of picoplankton in the oligotrophic ocean. Nature, Lond. 301 : 702-704

Prieur, L., Sathyendranath, S. (1981). An optical classification of coastal and oceanic waters based on the specific spectral absorption curves of phytoplankton pigments, dissolved organic matter, and other particulate materials. Limnol. Oceanogr 26: 671-689

Raimbault, P. (1984). Influence of temperature on the transient response in nitrate uptake and reduction by four marine diatoms. J. exp. mar. Biol. Ecol. 84: 37-53

Slawyk, G. (1980). Labsorption de compośes azotés par le phytoplancton marin. Thèse de Doctorat d'Etat, Univ. AixMarseille II

Slawyk, G., Maclsaac, J. J., Dugdale, R. C. (1976). Inorganic nitrogen uptake by marine phytoplankton under in situ and simulated in situ incubation conditions: results from the northwest African upwelling region. Limnol. Oceanogr. 21: 149-152

Steemann-Nielsen, E. (1952). The use of radioactive carbon $\left({ }^{14} \mathrm{C}\right)$ for measuring organic production in the sea. J. Cons. perm. int. Explor. Mer 18: 117-140

Strickland, J. D. H., Parsons, T. R. (1972). A practical handbook of seawater analysis. Bull. Fish. Res. Bd Canada 167

Voituriez, B. (1980). Campagnes CIPREA, L'upwelling équatorial du Golfe de Guinée. Juin-Septembre 1978. Résultats des campagnes à la mer. Publ. CNEXO, Brest. Vol. 19, p. 1-250

Voituriez, B., Herbland, A. (1984). Signification de la relation nitrate/température dans l'upwelling équatorial du Golfe de Guinée. Oceanologica Acta 7: 169-174

Walsh, J. J. (1976). Herbivory as a factor in patterns of nutrient utilization in the sea. Limnol. Oceanogr 21.1-13

Yentsch, C. S., Menzel, D. W. (1963). A method for the determination of phytoplankton chlorophyll and phaeophytin by fluorescence. Deep Sea Res. 10: 221-231 